\title{
Translation Method of English Into Indonesian Used in Movie Scripts and Their Application in Translation Teaching
}

\author{
Dwi Haryanti* \\ Sekolah Pascasarjana \\ Universitas Muhammadiyah Surakarta \\ Surakarta, Indonesia \\ dwi.harjanti@ums.ac.id \\ Atiqa Sabardila \\ Sekolah Pascasarjana \\ Universitas Muhammadiyah Surakarta \\ Surakarta, Indonesia \\ atiqa.Sabardila@ums.ac.id
}

\author{
Aryati Prasetyarini \\ Pendidikan Bahasa Inggris \\ Universitas Muhammadiyah Surakarta \\ Surakarta, Indonesia \\ aryati.prasetyarini@ums.ac.id \\ Farrah Zakiyah Anwar \\ Sekolah Pascasarjana \\ Universitas Muhammadiyah Surakarta \\ Surakarta, Indonesia \\ farrahzakiyahanwar@gmail.com
}

\author{
Mauly Halwat Hikmat \\ Pendidikan Bahasa Inggris \\ Universitas Muhammadiyah Surakarta \\ Surakarta, Indonesia \\ mauly.hikmat@ums.ac.id \\ Vira Cahya Mukti \\ Sekolah Pascasarjana \\ Universitas Muhammadiyah Surakarta \\ Surakarta, Indonesia \\ viracahyamukti@gmail.com
}

\begin{abstract}
The article discusses the classification of translation methods used in movie scripts and their application in translation teaching. The data were words, phrases, clauses, and sentences written in Aladdin and Harry Potter movie scripts and their translation. The data, both written in source and target languages, were compared then analyzed using Spreadly and Catford theories. Based on the analysis, it was found that the writers used eight translation methods namely, word-for word translation, literal translation, faithful translation, semantic translation, communicative translation, idiomatic translation, free translation, and adaptation. In addition, every translation method can be used as the examples in translation teaching. The steps in applying the translation methods were explaining the theory, asking students to translate English script movie into Indonesian, discussing the translation results in pair, explaining examples of translation methods, asking students to apply the examples of every translation method three times, assessing the results to evaluate the students' progress, discussing the translation result in applying translation methods, and feedback given to students. By applying the research result in teaching of translation, both students and lecturers felt more confident in learning and pratice translating text from a source language into a target one.
\end{abstract}

Keywords-translation method, movie script, translation teaching

\section{INTRODUCTION}

Translation is a process of transferring message from a source language into a target language equivalently. The process of translating text to others can be started by analyzing source language text (SL), transferring, and restructuring. The translator analyzes the SL text the terms of text style, text type, text structure, grammar of all linguistic units, terms used, and all message of the text. After grasping the message, translator transfers the message into the target language (TL). The final stage is restructuring, which the written result should be read more and more by comparing the SL message, choosing appropriate terms or words with their context, using natural grammar in the target text, and ensuring that the translation is readable. By transferring the message using the process, it is expected that translators can produce good translation, which can be seen from its accuracy, acceptability, and readability. To achieve it, translators commonly apply some strategies, technique, and methods.

Translation methods are the overall strategies applied by the translator in the process of transferring the message of SL into TL. Ordudori (2007), Newmark (1987), and Catford ((1965) mentioned eight translation methods, both in source language (SL) and Target Language (TL) emphasis. In source language, there are word-for-word translation, literal translation, semantic translation, and faithful translation. While in the target language, the methods are adaptation, free translation, idiomatic translation, and communicative translation. Word-for-word translation is often demonstrated as interlinear translation, with the same order between TL and SL. Newmark (1987) stated that the use of word-forwords translation is to understand the mechanics of the source language or to construe a difficult text as a pretranslation proces. This method helps the translator to convert the grammatical structure into the nearest target language. Literal translation applied in the SL grammatical constructions should be converted to the nearest TL equivalents but the lexical words are again translated singly and out of context as a pre translation process. Literal translation generally starts from word-to-word translation but makes changes in comformity with TL grammar, such as inserting additional words, changing structures at any ranks, etc. Free translation reproduces the matter that is really different with SL forms, or the content without the form of the original. Paraphrase is usually much longer than the originals. It is so-called intralingual translation, often prolix and pretentious and not translation at all (Newmark) (1987). This method can also be used in special purpose text such as in mass media. A faithful translation attempts to reproduce the exact contextual meanings of the original within the constraints of the TL grammatical structures. It transfers cultural words and preserves the degrees of grammatical and lexical abnormality in the translation. Newmark stated that it attempts to be completely faithful to the intentions and the 
text-realisation of the SL writer (1987). The use of faithful translation is classified as the beginning of translation process which still need some corrections. Adaptation is the freest form of the translation. It is used for plays such as commedies and poetry; the themes, characters, plots are usually preserved, the SL culture converted to the TL culture and the text rewritten (1987). Newmark stated that idiomatic translation reproduces the messages of the original but tends to distort nuances of meanings by preferring colloquialisms and idioms where these do not exist in the original (1987). The translator tries to find the meaning of idiom and uses the word choices correctly for TL. Semantic translation differs from faithful translation only in as far as it must take more account of the aesthetic values. The distinction between faithful and semantic translation is in the uncompromising and dogmatic, while the second allows for the translator's intuitive empathy with the original, admits the creative exception to $100 \%$ fidelity, and is more flexible in the TL. Communicative translation attempted to render the exact contextual meaning of the original in such a way that both content and language are acceptable and comprehensible to the readership (1987). It reproduces the SL contextual meaning to the TL and makes the message easily understood.

Research related to translation methods have been done by Kurniawan (2017) with different source text and data. Kurniawan analyzed metaphor expression found in The Vanished Man novel translated into Si Peramal. The finding indicated that metaphors are translated using literal and free translation, and addition. Other previous study done by Prasmawati (2016) indicated the translation method used by translator of I am Number Four novel. The translator of the novel used word-for-word translation, literal translation, faithful translation, free translation, idiomatic translation and communicative translation to translate passive voice in the novel. The method is used to gain equivalent meaning of the target language to the source one. Hidhaastria (2017) in her article said that the sixth ssemester students of English Education Department UIN Alauddin Makassar used free translation method, word-by-word translation method, literal translation method, and communicative translation method. In the research, the researcher recommended the lecturer to give motivation to the students to learn translation method, translation strategies and the lecturer would not be stuck only in some particular teaching strategy. Shifa (2013) in her thesis found 8 translation methods in translating $A$ Walk to Remember into Kan Kukenang Selalu namely, word for word translation, free translation, literal translation, faithful translation, and idiomatic translation and literal translation method. The last method constituted the most dominant method used by the translator. It is slightly different from this article which tries to show the application of translation methods in teaching translation practice. After finding the translation methods used in the movie scripts, they were used as the examples in translation teaching. From the activity, the researcher hopes the students understand the translation method not only the theory but also practice translating text and understanding their own method used. Furthermore, this research aims to classify the methods used by the translators in translating some works from English to Indonesian, and give clear understanding in their teaching application in the topics translation method.

\section{RESEARCH METHOD}

This article discusses the result of descriptive qualitative research. The data are utterances found in Harry Potter and Aladdin movie scripts and their translation. The data were collected using content analysis. They were analyzed using Spreadly and Catford theories (1965). Spreadly (2006) theory were domain analysis used to determine the appropriate data by comparing both English and Indonesian utterances, taxonomy analysis and Catford theory were applied to classify the translation methods, componential analysis tried to explain the marker every method and a cultural theme analysis which can be applied to describe the accuracy based on the cultural context.

\section{FINDINGS AND DISCUSSION}

This section discusses the findings and discussion focusing on the translation method used in translating from English into Indonesian and the steps of translation teaching using examples of the first research finding to teach translation method in translation class. All the translation methods can be seen in the following table.

Tabel: Translation mehods found in Alladin and Harry Potter

\begin{tabular}{|c|c|}
\hline Number & Translation Mehods \\
\hline 1. & Word-for-word \\
\hline 2. & Literal \\
\hline 3. & Fathfull \\
\hline 4. & semantic \\
\hline 5. & communicative \\
\hline 6. & Idiomatic \\
\hline 7. & Free \\
\hline 8. & Adaptation \\
\hline
\end{tabular}

What follows are the results of the analysis.

1. Translation Method Found in the Movie scripts and Their Translation

The findings show that there are eight methods applied by the translators of Aladdin and Harry Potter movie scripts and their subtitling namely, word-for-word translation, literal translation, faithful translation, semantic translation, communicative translation, idiomatic translation, free translation, and adaptation. The samples of the finding are described as follows.

a. Word-for-word translation

The translator transferred the sentence covertly due to the similar word order between source language to target language.

SL: Correction, the monkey stole it.

TL: Koreksi, monyet mencuri-nya

Both sentences have equivalent message and the same word order. Correction was translated into koreksi, the monkey into monyet, stole into mencuri, and it into nya. The translation can be categorized into word-for-word translation due to the fact that both sentences have same word orders.

SL: I won't give up.

TL: Aku tidak akan menyerah.

Word-for-word translation was used in transferring the message by translating $I$ into $A k u$, won't into tidak akan, and 
give up into menyerah. By using the method, the message of both utterances does not change.

\section{b. Literal translation}

Literal refers to the method that can be used to translate the nearest grammatical form between the source and target text.

SL: Why would I say "as people"?

TL: Kenapa kukatakan "antar manusia"?

The English and Indonesian have the same meaning contextually. The translator did not translate word-for-word because there is a slight difference between the two expressions. Why would you say as people? Was translated into Kenapa ku katakan antar manusia? The word would was deleted by the translator to make the target expression natural.

\section{SL: I heard the bell pealing from the church.}

TL: Aku mendengar bunyi lonceng gereja.

The two sentences above have the same meaning and to reach it, the translator used literal translation by restructuring the TL expression that has the nearest word order between the target and source languages.

\section{c. Faithful translation}

Faithful translation was used to reproduce contextual meanings of the original within the restriction of the TL grammatical structures.

SL: I'm sorry for the jams, and the jewels... and the buying you.

TL: Maaf soal selai, perhiasan.....dan soal membelimu.

The English expression was translated into Indonesian with the same meaning using faithful translation. The structure of English language was translated by reproducing target language structure naturally without distorting the message, so that the translation can be classified into accurate.

SL: The storm was terrible last night.

TL: Tadi malam badai hebat.

The two sentences above have the same meaning. The method of doing the translation was classified as faithful. In the datum, the translator tried to express in natural target language without changing the equivalent message. The English expression was translated using faithful translation. There was no distortion of meaning in the Indonesian although the structure of both sentences is different. The translator focused on the message of both languages.

\section{d. Semantic translation}

Semantic translation was used in transferring the source message into the target one. The translation was done based the semantic meaning to maintain the similar meaning of both utterances. It refers to compromising the meaning that makes concession to the readers.

SL: Oh, I wish I could see the world above the sea.

TL: Oh, seandainya aku bisa melihat dunia di atas laut.

Semantic translation was applied by the translator to transfer the message of source language sentence into the target one. The English sentence massage is transferred semantically without considering every word separately but as the sentence unity. By using the method, the translator tried to maintain the similar meaning of both expressions.
SL: Are you suggesting I am for sale?

TL: Maksudmu aku barang dagangan?

Semantic translation was used to get the similar message between target to source languages. The expression was transferred communicatively based on the sentence unity contextually. The translation result can be categorized into accurate translation.

e. Communicative translation

It refers to allowing the translator's intuitive transfer the message with the original expression.

SL: I was noticing how pleasant the evening is.

TL: Kulihat malam ini menyenangkan.

The English expression was translated communicatively in the target language without restricting the source language forms and preserve message accuracy.

SL: The light from the city look like the stars in the sky.

TL: Cahaya lampu kota tampak seperti bintang di langit.

Intuitively, the translator transferred the meaning of source language into the target language without bounding the source words form. He also attempted to gain same meaning between target to the source language.

f. Idiomatic translation

Idiomatic translation was used by the subtitlers when finding idiomatic expression. It is an expression that its meaning cannot be traced from each word that formed it.

SL: He's a lovely monkey.

TL: Dia lucu.

He is lovely monkey is idiomatic expression that was translated into Dia lucu. The translator or subtitler understood the English expression contextually. The meaning of the two expressions is not different and expressed naturally in the target text.

g. Free translation

Free translation was applied in the two movies. They reproduced the matter that was different from SL forms, or the content without the form of the original.

SL: I, uh, don't believe we've been properly introduced.

TL: Kita belum berkenalan.

The Indonesia expression was written shorter than the original but both of the utterances had no different meaning. The clear word used was only verb introduce that was transferred into berkenalan in verb.

h. Adaptation

Adaptation was used by the translator due to the fact that there were appropriate words in TL.

SL: My Sultan, our enemies grow stronger every day...yet you allow your daughter to dismiss Prince Anders and a possible military alliance.

TL: Sultan, musuh kita Semakin kuat dan kau biarkan putrimu menolak pangeran Anders beserta aliansi militer.

The translator or subtitler borrowed SL words by adaptation the pronunciation and spelling such as military into military and alliance into militer and aliansi. The 
adaptation did not change the message and it was done to make the expression easily understood by any readers.

2. The Application of Translation Methods Found in this Study in Teaching of Translation

Each translation method in the previous findings can be used as the examples in teaching of translation methods itself. The simple steps in applying the first finding in teaching translation methods are described below.

a. As the introduction, the lecturers explained the translation theory, including some topics, such as translation process, translation equivalence, translation strategies, and translation methods. All the topics were clarified by giving example taken from taken from both literary works (Aladdin and Harry Potter). These samples are to give the students clear understandings in how to apply the translation methods. The lecturers can combine this strategy with questioning. Students are given opportunity to ask many questions related to the lecturers' explanation.

b. After explaining the translation theories and methods, the lecturers asked the students to translate English script movie into Indonesia by translating different literary works. The students may choose their favorite English movies, such as The Lord of the Ring, Alice in Wonderland, or Beauty and the Beast. This step was done individually, so the lecturers gave enough time for the students to do the work.

c. The third step is giving the students opportunity to work in pair. The students may swap the works they have translated to the friend next to them, and discuss it. The students read their peer's work and give feedback. The lecturers visit each group to observe and assist the students if needed.

d. Fourth, the lecturers take some examples of translation methods used by some students and explain it to the class they handled. As the lectures are visiting every group, they may find both appropriate and inappropriate translation results done by the students. Then, the lecturers explain the finding before the class. This is done in order that the students have more clear understanding about the translation methods they apply.

e. The fifth step is that the students are given three times opportunities to apply the examples of each translation method. For instance, student A has to translate by using word-for-word method. Then the other students should follow the way he/she translates by using that method. After applying word-for-word method, the students are asked to check their friends' works. In this case, they should swap their translation result to the other students.

f. The sixth step is that the lecturers ask their students to evaluate their friends' work and question why their friend's work was done in such a way. Moreover, the students should revise their own translation based on their friend's suggestion.

g. The last is evaluation that should be done to measure the students' achievement. The lecturer may discuss the translation result which has been completed by the students in applying the translation methods. The lecturers should also give feedback to the students so that they are able to find their weaknesses and their mistakes in translating English works into Bahasa Indonesia. In addition, the lecturers should ensure that all of their students do the tasks in order to improve their skill in translation. They also should be aware of what their lecturers have suggested related to their weaknesses in translation.

The two results support each other because translation method found in the movie scripts and their translation that can be used as the examples of teaching translation method topic related to Ordudori (2007) explanation. It refers theory translation method proposed by Newmark (1987). Using the research result of translation methods in teaching its topic, the students of translation class can understand more about the theory of translation method and the reality used in movie script translation. The nine translation methods and their examples are appropriate material used in teaching translation methods in translation class.

\section{CONCLUSION}

The translation activity related to practice translating a language, understanding theory, and conducting research. The research result on translation can be utilized in the teaching of translation. The research result of translation methods used in movies script of Aladdin and Harry Potter which consist of word-for-word translation, literal translation, faithful translation, semantic translation, communicative translation, idiomatic translation, free translation, and adaptation can be applied in translation teaching. The students may choose their favorite English movies to be translated using those methods as the examples. It is recommended that any results on translation is utilized and applied in the teaching of translation as it will enrich students' knowledge as well as experience in translating text of a language to another.

Students may swap the works they have translated to the friend next to them and discuss it. The lecturers took some examples of translation methods used by some students and explained it to each class they handled. The fourth step, the students had three times opportunities to apply the examples of each translation method. For instance, student A has to translate by using word-for-word method. Then the other students should follow the way he/she translates by using that method. After applying word-for-word method, the students are asked to check their friends' works. In this case, they should swap their translation result to the other students. In the fifth step, the lecturers asked their students to correct their friends' work and question why their friend's work was done in such a way. Moreover, the students should also revise their own translation based on their friend's suggestion. The evaluation should be done to measure the students' achievement. The lecturer may discuss the translation result which has been completed by the students in applying translation methods. The lecturers should also give feedback to the students so that they are able to find their weaknesses and their fault in translating English works to Bahasa Indonesia. In addition, the lecturers should ensure that all of their students do the tasks in order to improve their 
skill in translation. They also should be aware of what their lecturer has suggested related to their weaknesses and fault in translation.

\section{REFERENCES}

Ordudari, Mahmoud. (2007). Translation Procedures, Strategies And Methods. TranslationJournal.net 11 (3). Retrieved from .https://translationjournal.net/journal/41culture.htm

Newmark, Peter. (1987). A Textbook of Translation. London: Prentice Hall. Catford, J. C. (1965). A Linguistic Theory of Translation. Oxford: Oxford University.

Kurniawan, Ade Danu; Eni Rosnija, dan Luwandi Suhartono. Analysis of English_Indonesian Trnaslation Method in Transalting Metaphor in the Vinished Man Novel. Jurnal Pendidikan dan Pembelajaran Khatulistiwa, 6 (3).

Http://Jurnal.Untan.Ac.Id/Index.Php/Jpdpb/Article/View/18858
Prasmawati, Maratina Indah. (2016). An Analysis on Translation Method and Quality of Passive Voice in I am Number Four Novel by Nur Aini. Retrieved

http://eprints.ums.ac.id/40587/1/PUBLICATION\%20ARTICLE.pdf

Hidhaastria, Herti. (2017). An Analysis Of Translation Method Used By Students At The Sixth Semester Of English Education Department Uin Alauddin Makassar. Retrieved from http://repositori.uinalauddin.ac.id/8040/1/HERTI\%20HIDHA\%20ASTRIA.pdf

Shifa, Mustika. (2013). Translation Methods In "A Walk to Remember" Novel Translated into "Kan Kukenang Selalu”. Retrieved from Http://Eprints.Dinus.Ac.Id/5865/1/Thesis.Pdf

Spradley, James. (2006) Metode Etnografi. Yogyakarta: Tiara Wacana. 